\title{
Microbiological, Cytological and Immunolgical Investigation of Endometritis in Arabian Mares
}

\section{Mona MH Soliman ${ }^{1 *}$, Eman Ragab ${ }^{2}$, Sally Ibrahim $^{3}$, Youssef Ahmed ${ }^{3}$}

${ }^{1}$ Department of Microbiology and Immunology, Veterinary Research Division, National Research Centre, Doki, Egypt; ${ }^{2}$ Department of Microbiology, Faculty of veterinary medicine, Cairo University, Cairo, Egypt; ${ }^{3}$ Department of Animal Reproduction and A.I, Veterinary Research Division, National Research Centre, Dokki, Egypt.

\begin{abstract}
Endometritis is the principal reason of reduced reproductive efficiency in female horses. Bacteriological, mycological and cytological investigations are the backbone of detecting endometritis in mares. Interleukin-6, Prostaglandin $\mathrm{E}_{2}$ and Prostaglandin $\mathrm{F}_{2 \alpha}$ are pro-inflammatory cytokines and their determination in serum of mares is important to predict early stages of endometritis to prevent its detrimental effect on fertility of mares. Low volume lavage (LVL) fluid was microbiologically examined (bacteria and fungi) together with cytological smears from endometrial swabs. Microbial growth on culture of the LVL pellet revealed that diseased mares had Gram-negative bacteria such as E. coli (75\%), Klebsiella spp. (40\%), Gram-positive bacteria such as Staphylococcus aureus (60\%) and Staphylococcus epidermidis (55\%). For mycological results; there were 25 (25\%) diseased mares showed positive results for yeasts and moulds as 13 were positive for yeasts and 12 for moulds. Microbial examination together with cytological results revealed that endometritis was diagnosed in 80 out of 100 mares. Serum evaluation of IL6, $\mathrm{PGE}_{2}$ and $\mathrm{PGF}_{2 \alpha}$ revealed their higher levels in diseased mares (83\%) compared with control ones. In conclusion, microbiological examination of endometrial Low volume uterine lavage is of great importance to diagnose precisely the causative agent either bacteria or fungi. Microbiological together with cytological smears and clinical finding are crucial when evaluating mares. The IL6, $\mathrm{PGE}_{2}$ and $\mathrm{PGF}_{2 \alpha}$ determination in serum can detect early stages of endometritis to quickly treat those cases.
\end{abstract}

Keywords | Bacteriology, Cytology, Mare endometritis, Mycology, Pro-inflammatory cytokines

Received | June 20, 2021; Accepted | September 02, 2021; Published | October 15, 2021

*Correspondence | Mona MH Soliman, Department of Microbiology and Immunology, Veterinary Research Division, National Research Centre, Doki, Egypt; Email: mona_nrc.micro@yahoo.com

Citation Soliman MMH, Ragab E, Ibrahim S, Ahmed Y (2021). Microbiological, cytological and immunolgical investigation of endometritis in Arabian mares. Adv. Anim. Vet. Sci. 9(12): 2077-2083.

DOI | http://dx.doi.org/10.17582/journal.aavs/2021/9.12.2077.2083

ISSN (Online) | 2307-8316; ISSN (Print) | 2309-3331

Copyright $(\subseteq 2021$ Soliman et al. This is an open access article distributed under the Creative Commons Attribution License, which permits unrestricted use, distribution, and reproduction in any medium, provided the original work is properly cited.

\section{INTRODUCTION}

$T$ The determination of endometritis is basic within the veterinarian's endeavors to cure infertility in mares. Methods which are accessible to detect endometritis include clinical investigation, transrectal palpation, ultrasonography of the genital tract, uterine culture, vaginal speculum inspection, endometrial biopsy and cytology (Riddle et al., 2007).

Subclinical and clinical endometritis are the principal causes of decreased reproductive performance in mares. Clinical endometritis is somewhat simple to detect during regular physical and ultrasonographic reproductive checking, while the diagnosis of subclinical endometritis needs more detailed work-up (Aitken, 2012).

Bacterial endometritis is assumed the foremost crucial reproductive illness in the mare and is related with server financial losses. On the other hand, in non-venereal bacterial endometritis, hazard determinants such as reduced uterine defense techniques or bad perineal configuration, instead of the bacterial elements, form the principal trouble (Causey, 2006).

Fungal endometritis is not frequent condition in mares, 
with a reported incidence of less than $5 \%$ of diagnosed endometritis. The prognosis of fungal endometritis in mares is mainly poor, either because the fungal elements resist eradication or because they afterwards return. The principal reasons for treatment failure are proposed to include the resistance of invasive shapes to intrauterine treatment, failure to eradicate the predisposing determinants or recontamination from a reservoir in the caudal reproductive system. On the other hand, some cases of fungal endometritis recover suddenly or without particular treatment, probably since the disturbances that permitted fungal colonization have been adjusted (e.g., expulsion of a necrotic focus) (Stout, 2008).

Mares suffering from mycotic endometritis are often elder, multiparous female horses with a history of constant barrenness. Clinical features may include a purulent vaginal secretion and large amounts of flocculent discharge inside the uterine lumen on palpation and ultrasound investigation though other cases may be subclinical. Differentiation between the diverse shapes of mycotic elements is crucial while choosing remedy and evaluating in vitro sensitivity testing for every isolate is suggested, as sensitivities to commonly utilized antifungals differ accordingly. Moreover, it is common that mycotic infection is opportunistic and can only affect chronically disordered uterine/vaginal environment, pneumovagina, continuous endometritis and frequent intrauterine antimicrobial treatment are known as predisposing issues (Scott, 2020).

Cytological and microbiological investigations of uterine swabs are the backbone in the diagnosis of acute endometritis in female horses (Walter and Wehrend, 2007). With microbiological analysis alone, there is a chance for inaccurate judgment on the examinations because of falsepositive and false-negative culture outcome (Moller, 2005; LeBlanc and Causey, 2009). Moreover, a positive culture might not be related with endometritis and decreased fertility (Moller, 2005; LeBlanc et al., 2007).

Subclinical endometritis is affected by the sort of pathogen and the mare's subsequent immunological reaction (LeBlanc and Causey, 2009; Overbeck et al., 2011). However, isolation of bacterial organisms does not fundamentally assure the existence of endometritis. (Riddle et al., 2007; LeBlanc, 2010).

Cytological investigation of a uterine specimen is a highly valuable diagnostic test, and various scientists have set its sensitivity over that of microbiological investigation (Riddle et al., 2007). There are different approaches to classify the cytological outcome; some researchers report the number of polymorphonuclear leukocytes (PMNs) as a percentage of all cells observed in a slide (Couto and Hughes, 1985;
Ricketts and Mackintosh, 1987) whereas others report real numbers of cells observed per microscopic field inspected (Knudsen, 1964; Purswell et al., 1989). Endometritis is most associated with aerobic bacteria (Riddle et al., 2007).

Interleukin-6 is well-known to be a cytokine that created by T cells. T cells are categorized mainly into Th 1 and Th 2 by the criteria of cytokine generation. The Th1 cell influences cell mediated immunity by creating basically IL-2, TNF- $\alpha$, and IFN- $\gamma$, and the Th2 cell influences antibody generation by producing primarily IL-4, IL-5, IL-6, IL-10 and IL-13 (Mosmann et al., 1986).

Elevated level of IL-6 in the prepartum period tended to predict endometritis. Alteration in the measurements of IL-6 level amid pregnancy is valuable method for anticipating problems in postpartum reproductive disorders as postpartum retained placenta, endometritis and/or follicular cyst (Ishikawa et al., 2004).

Prostaglandins are lipid compounds originated enzymatically from arachidonic acid. The reproductive tract is the main generator of $\mathrm{PGE}_{2}$ and $\mathrm{PGF}_{2 \alpha}$. The involvement of prostaglandins in pain, infertility, angiogenesis, tissue remodeling, and cell proliferation in addition to different pathological issues is well studied by different authors (Rakhila et al., 2015). Thus, the present work was planned to diagnose endometritis in Arabian mares using microbiological and cytological examination together with IL6, $\mathrm{PGE}_{2}$ and $\mathrm{PGF}_{2 \alpha}$ assessment.

\section{MATERIALS AND METHODS}

A total of 100 Arabian mare specimens aged from '8-14' years old were collected from stud farms, Giza, Egypt. These specimens were gathered just once from each female horse during the estrus, after mares owner's agreement.

\section{ENDOMETRIAL SWABS}

Mare's tails were held out way to prevent any probable contamination then perineal region was washed with cleanser and washed with clean water for at least thrice to properly clean the area. A while later, the perineal region was dried with expendable tissues. The inspected specialist put a long clean obstetrical sleeve and used a little sum of germ-free lubricator. The double-guarded culture swab (IMV advances, Paris) was directed physically through the genitalia from the vulva, vagina, and cervix and finally inside the uterus. The swab was introduced and delicately twisted for about fifteen seconds, and after that was withdrawn from the guard, as well as one side was rolled onto a clean magnifying lens glass slide for cytological examination. It was carried out according to methods described by (LeBlanc et al., 2007; Bohn et al., 2014). 
LOW VOLUME UTERINE LAVAGE (LVL)

The LVL was done as already explained by (LeBlanc et al., 2007; Bohn et al., 2014). In brief, the inspected specialist passed Equine Catheter (IMV advances, Paris) via the cervix into the uterus, the balloon swelled, and the catheter at that point was situated inside cervical os. Around $300 \mathrm{ml}$ of sterile normal saline $(0.9 \% \mathrm{NaCl})$ was passed through the uterus. After two minutes, a massage was done to the uterus by means of transrectal palpation for thirty- second and the liquid was hence collected by gravity stream into the original liquid sac. A while later, the initial liquid bag that contained uterine lavage was kept on ice till transportation to the lab for microbiological examination. The characters of the cloudy LVL fluid were evaluated visually into: normal (clear) or abnormal (discolored and debris) was documented.

\section{MicrobiologicAl EXAMINATION}

\section{BACTERIAL ISOLATION AND IDENTIFICATION}

Uterine lavage specimens were sub-cultured into blood agar (Blood agar, 10\% defibrinated horse blood in blood agar base), Mannitol salt agar, MacConkey's agar and were kept at $37^{\circ} \mathrm{C}$ for 24 hours. Inoculated plates were inspected for bacterial growth after ' $24-48$ ' $\mathrm{hr}$ for grown colonies; 3-5 colonies from each sort were picked up and were plated on to Blood agar plates for testing hemolytic potential and purification of microbes. The characterization was performed according to cultural, morphological and biochemical properties in accordance to methods described by (Carter, 1984; Holt et al., 1994).

\section{Mycological EXAMination}

Mare uterine lavage samples were streaked on Sabouraud Dextrose Agar plates and were kept at $30^{\circ} \mathrm{C}$ for ' $3-5$ ' days. The inoculated plates were inverted to prevent spreaders. The characteristics of yeast colonies that they were of different colors as white, creamy, yellow and pink and they may be regular or irregular in shape but for mould the colonies appeared as star-shaped with different colors. Soliman et al. (2019). Pure colonies were subjected to macroscopic, microscopic and differential biochemical identification assays as described by (Fisher and Cook, 1998; Samson et al., 2010).

\section{Cytological EXAMination}

The slide samples collected from mare swabs were fixed and colored with a particular commercial cytological stain; Papanicolaou assay (Biodiagnostic, Egypt), concurring to manufacture's method. We assessed the slides in respect to the features of cell morphology, cellularity, count of inflammatory cells per 400X field, along with any other notable characteristics (LeBlanc et al., 2007; Bohn et al., 2014).

\section{Determination of IL6, PGE And PGF $_{2 a}$}

IN SERUM OF INVESTIGATED MARES

Serum levels of IL- 6 were detected by equine interleukin 6 (IL-6) ELISA kit (SunLong Biotech Co., LTD, Zhejiang, China) and was utilized as reported by the producer's directions. The test sensitivity and ranges were $0.5 \mathrm{pg} / \mathrm{ml}$ and $1.6 \mathrm{pg} / \mathrm{ml}$ to $100 \mathrm{pg} / \mathrm{ml}$, respectively.

For $\mathrm{PGF}_{2 \alpha}$ concentration, the commercial $\mathrm{PGF}_{2 \alpha}$ high sensitivity equine prostaglandin $\mathrm{F}_{2 \alpha}$ ELISA kit (SunLong Biotech Co., LTD, Zhejiang, China) was utilized and performed as stated in the producer's directions. The test sensitivity and range were $0.5 \mathrm{pg} / \mathrm{ml}$ and $3 \mathrm{pg} / \mathrm{ml}$ to $210 \mathrm{pg} / \mathrm{ml}$. To avoid the destruction of prostaglandins; serum was blended with a $1 \%$ stabilizing solution $0.3 \mathrm{M}$ ethylenediaminetetraacetic acid (EDTA) (Sigma) and 1\% aspirin (Sigma).

\section{STATISTICAL ANALYSIS}

The obtained data were statistically analyzed for descriptive statistics using SPSS 14. For analysis of serum IL6, $\mathrm{PGE}_{2}$ and $\mathrm{PGF}_{2 \alpha}$ in mares, the unpaired t test with Welch's correction (GraphPad Software, Inc., San Diego, CA, USA) was used for statistical analysis of IL-6, $\mathrm{PGE}_{2}$ and $\mathrm{PGF}_{2 \alpha}$ between control healthy and diseased (endometritis) groups. The $\mathrm{P}$ values $\leq 0.05$ were constituted statistically significant. Graph Pad Prism 9.0 was utilized for performing statistical investigation.

\section{RESULTS AND DISCUSSION}

\section{Microbiological Results}

Results of aerobically growing bacteria from uterine lavage specimens of the examined mares revealed that diseased mares had Gram negative-bacteria such as Escherichia coli (75\%), Klebsiella spp. (40\%), Gram positive-bacteria as Staphylococcus aureus (60\%) and Staphylococcus epidermidis $(55 \%)$.

Regarding fungal results; there were 25 (25\%) diseased mares showed positive results for yeast and mould growth colonies as 13 were positive for yeasts (13\%) and 12 were positive for moulds (12\%) and the isolation rates for each isolate were Candida albicans (7\%), Candida glabrata (5\%), Rhodotorula (1\%), Aspergillus fumigatus (5\%), Mucer (4\%), Penicillium (2\%) and finally Alternaria (1\%). These diseased mares were also positive for bacterial cultures (mixed infection). The microbiological examination results together with mixed infections are being presented in Table 1.

\section{Cytological eXamination}

The positivity of endometrial cytology was confirmed if ( $\geq$ 1 neutrophil for high power field, or $\geq 1 \%$ neutrophil to 


\section{OPEN $\odot$ ACCESS}

epithelial cell proportion (1:100). While female horses were considered as having endometritis when the inflammatory cells were basically neutrophils, as clear in (Figures 1 and 2) and in the present study, $80 \%$ of the examined mares were positive for endometrial cytology smear.

Table 1: The microbiological examination results together with mixed infections.

\begin{tabular}{|l|l|}
\hline Isolated microorganism & $\begin{array}{l}\text { Number } \\
\text { of isolates }\end{array}$ \\
\hline E. coli & $75(75 \%)$ \\
\hline Klebsiella spp. & $40(40 \%)$ \\
\hline Staphylococcus aureus & $60(60 \%)$ \\
\hline Staphylococcus epidermidis & $55(55 \%)$ \\
\hline Candida albicans & $7(7 \%)$ \\
\hline Candida glabrata & $5(5 \%)$ \\
\hline Rhodotorula & $1(1 \%)$ \\
\hline Aspergillus fumigatus & $5(5 \%)$ \\
\hline Mucer & $4(4 \%)$ \\
\hline Penicillium & $2(2 \%)$ \\
\hline Alternaria & $1(1 \%)$ \\
\hline Microorganisms combination & \\
\hline E. coli + Klebsiella spp. & $33(33 \%)$ \\
\hline E. coli + Staphylococcus aureus & $24(24 \%)$ \\
\hline Klebsiella spp.+Staphylococcus epidermidis & $10(10 \%)$ \\
\hline Staphylococcus aureus + Staphylococcus epidermidis & $25(25 \%)$ \\
\hline Bacterial isolates + yeasts & $13(13 \%)$ \\
\hline Bacterial isolates+ Moulds & $11(11 \%)$ \\
\hline
\end{tabular}

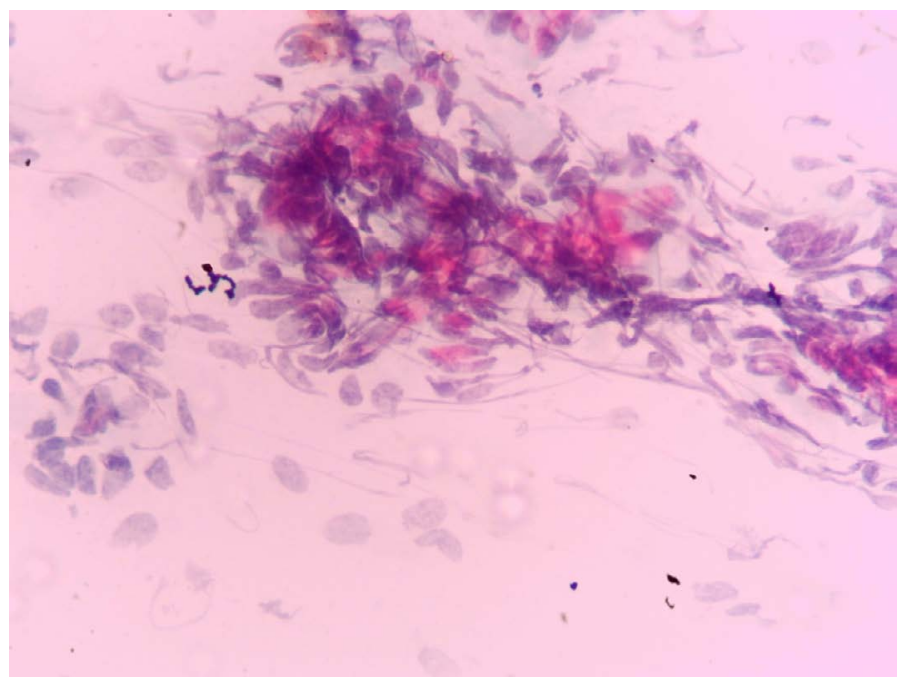

Figure 1: Negative endometrial cytology smear of mares as only endometrium epithelial cells can be seen and no inflammatory cells was observed.

SERUM LeVEls of IL-6 AND PROSTAGLANDins ( $\mathbb{E}_{2}$ AND $\mathrm{F}_{2 \alpha}$ ) IN EXAMINED MARES

Serum levels of IL-6, $\mathrm{PGE}_{2}$ and $\mathrm{PGF}_{2 \alpha}$ in mares with endometritis (diseased) were elevated in $83 \%$ from total examined mares when compared with control ones as shown in Table 2. Serum levels of IL-6 were greater $(P<0.001)$ in diseased female horses $(40.5 \pm 0.65 \mathrm{pg} / \mathrm{ml})$ compared to the control ones $(20 \pm 0.41 \mathrm{pm} / \mathrm{ml})$. Also, serum levels of $\mathrm{PGE}_{2}$ showed higher concentrations $(P<0.001)$ in the diseased female horses $(40.75 \pm 1.11 \mathrm{pm} / \mathrm{ml})$ compared to the healthy ones $(13.5 \pm 0.65 \mathrm{pm} / \mathrm{ml})$. Concentrations of $\mathrm{PGF}_{2 \alpha}$ in serum showed a remarkable raise $(P<0.001)$ in the diseased female horses $(208.5 \pm 3.18 \mathrm{pg} / \mathrm{ml})$ compared to the healthy ones $(125.75 \pm 2.17 \mathrm{pg} / \mathrm{ml})$.

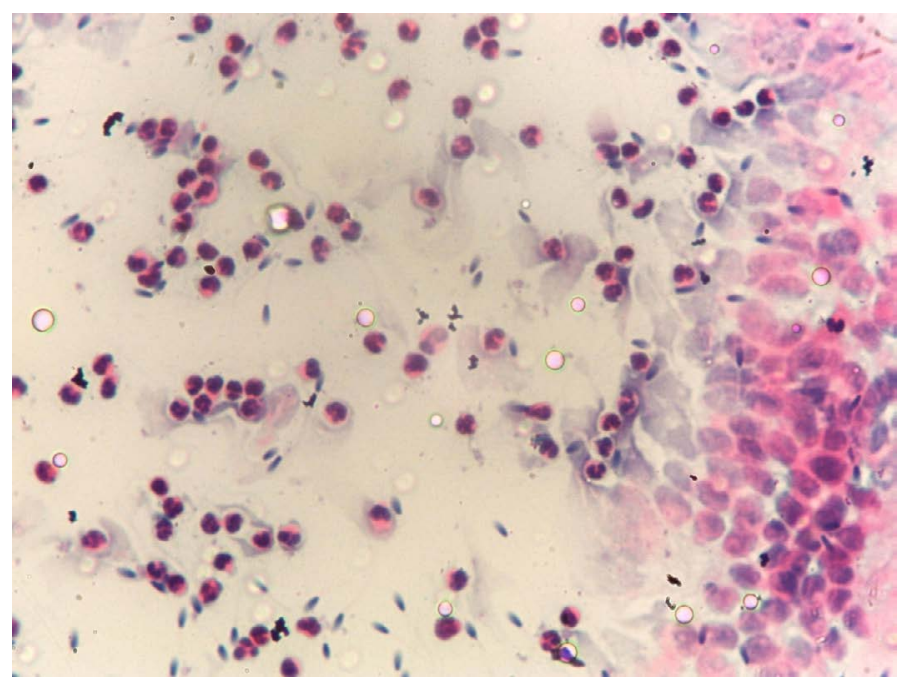

Figure 2: Postive endometrial cytology smear as a few endometrium epithelial cells was observed together with hypersegmented neutrophils.

Table 2: The serum levels of IL-6 and prostaglandins $\left(\mathrm{E}_{2}\right.$ and $\left.\mathrm{F}_{2 \alpha}\right)$ in mares suffering from endometritis (Mean $\pm \mathrm{SE}$ ) compared to control ones.

\begin{tabular}{|c|c|c|}
\hline $\begin{array}{l}\text { Tested parameter } \\
(\mathrm{pg} / \mathrm{ml})\end{array}$ & $\begin{array}{l}\text { Levels in diseased } \\
\text { mares (Mean } \pm \text { SE) }\end{array}$ & $\begin{array}{l}\text { Levels in control } \\
\text { mares }(\text { Mean } \pm S E)\end{array}$ \\
\hline IL6 & $40.5 \pm 0.65^{5 * *}$ & $20 \pm 0.41$ \\
\hline $\mathrm{PGE}_{2}$ & $40.75 \pm 1.11^{\prime-}$ & $13.5 \pm 0.65$ \\
\hline $\mathrm{PGF}_{2 \alpha}$ & $208.5 \pm 3.18^{-* *}$ & $125.75 \pm 2.17$ \\
\hline
\end{tabular}

In the present study, endometritis was confirmed if the mare presented two or more of the parameters in the following checklist: (1) atypical clinical finding; (2) unusual characteristics of uterine lavage (LVL) liquid; (3) positive endometrial cytology smear; and (4) positive microbial culture of the uterine lavage LVL pellet. Briefly, endometritis was detected in 80 out of 100 female horses that had been tested. Subsequently, it is extremely critical to combine clinical discoveries and laboratory information, when assessing female horses for endometritis (Amorim et al., 2016).

Endometritis has a prominent economic effect. Infected female horses usually have abnormal estrous cycles, need thorough clinical breeding care, and need additional cycles 
to become pregnant, increasing extra expenses to the owner (Thalheimer and Lawrence, 2001). Those expected high costs are the result of low reproductive performance, and only about $50-60 \%$ of mares are anticipated to give a healthy foal after a sole breeding (Bosh et al., 2009).

Endometrial culture and cytology are diagnostic for identifying mares with endometritis, as pregnancy rates were decreased when either culture or cytology were positive (Riddle et al., 2007).

In the present work, a total of 100 samples were gathered from Arabian female horses. Results of aerobically growing bacteria from the Uterine lavage specimens of the examined mares revealed that diseased mares had Gram-negative bacteria as E. coli (75\%), Klebsiella spp. (40\%), Gram-positive bacteria as Staphylococcus aureus (60\%) and Staphylococcus epidermidis (55\%) but Riddle et al. (2007) obtained different results as they mainly isolated the beta-bemolytic Streptococcus (78 specimens, 34\%), followed by $E$. coli (17\%), Pseudomonas spp. (11.7\%) also non-pathogenic microbes (11.3\%; Micrococcus, Bacillus and alpha Streptococcus) and Staphylococcus, Klebsiella, Proteus or Enterobacter cloaca were isolated in lower rates. Similar results to ours were obtained by Albihn et al. (2003) as they mostly isolated was $E$. coli (104 isolates) from total 239 mares also Frontoso et al. (2008) obtained different results from ours as they mostly isolated Beta haemolytic Streptococcus $31.7 \%$, followed by $18.4 \% \mathrm{E}$. coli from total 347 isolates from total 586 uterine swab samples from mares suffering from fertility problems and Troedsson (2011) also isolated mostly beta-bemolytic streptococci (Streptococcus equi ssp. zooepidemicus), Escherichia coli, Klebsiella pneumoniae, and Pseudomonas aeruginosa from mares'reproductive tracts. Other aerobic bacteria are alphahemolytic streptococci, Staphylococcus spp., Corynebacterium spp., Acinetobacter spp., Enterobacter spp., Citrobacter spp. and Proteus spp.

Fungi are classified into yeasts and moulds. Certain mycotic microorganisms like Candida species are dimorphic and have the capability to live in both yeast and mould forms under certain conditions (Beltaire et al., 2012).

Regarding fungal results; there were 25 (25\%) diseased mares showed positive results for yeast or mould growth colonies as 13 were positive for yeasts (13\%) and 12 were positive for moulds (12\%) and the isolation rates for each isolate were Candida albicans (7\%), Candida glabrata (5\%), Rhodotorula (1\%), Aspergillus fumigatus (5\%), Mucer (4\%), Penicillium (2\%) and finally Alternaria (1\%). These diseased mares were also positive for bacterial cultures (mixed infection), however, Riddle et al. (2007) isolated yeast from $17 \%$ from the examined mares. Beltaire et al. (2012) obtained similar results to ours as they identified 102 mycotic isolates 69\% were yeasts (mainly Candida species), 26\% moulds with septated hyphae (mainly Aspergillus species (18\%) and 5\% mould with non-septated hyphae (mainly Mucor species). Albihn et al. (2003) isolated 16 fungal isolates from total 239 mares, 15 isolates were yeasts and only one mould isolate. Lower isolation rate of yeasts was obtained by Frontoso et al. (2008) as they isolated yeasts from $2 \%$ from a total of 347 isolates from total 586 uterine specimens from mares with fertility complaint.

Collectively, pregnancy rates were badly influenced by both positive endometrial cytology and culture outcome. Twice as numerous female horses were analyzed as suffering from endometritis using cytology result than by culture technique, with the level of inflammation more decisive in determining infertility than the lowered existence or absence of inflammation (characterized as $>2$ neutrophils). Detection of microbes is often related with diminished pregnancy rates, regardless of cytological smear outcome. The uterine inflammatory profile, as recognized in cytological slides, found to vary among microbes, with beta-hemolytic Streptococcus being connected with more number of positives cytology than coliforms. At last, veterinarians ought to continuously interpret their laboratory outcome with carefulness, unless clinical results assure the existence of endometritis (Riddle et al., 2007).

IL-6 is a cytokine that was stated to be elevated in the peritoneal fluid of women with endometritis. This cytokine may be included in inflammatory changes and macrophage arousal (Wu and Ho, 2003).

In the current work, the serum levels of IL-6 were notably elevated in female horses with endometritis compared with healthy ones. Kasimanickam et al. (2013) assured that cows with clinical and subclinical endometritis exhibited elevated serum levels of IL-6 when compared with normal cows $(\mathrm{P}<0.05)$.

During the last decade, intensive analysis on molecular mechanisms causing the pathological course of endometriosis have been handled. Although numerous variables have been described to be included in these processes, prostaglandin $\mathrm{E}_{2}\left(\mathrm{PGE}_{2}\right)$ no doubt constitute as one of the foremost basic regulators of all. Accumulating data demonstrate that $\mathrm{PGE}_{2}$ controls many critical functions, such as steroidogenesis, angiogenesis, proliferation, and immune suppression that contribute to the pathogenesis of endometriosis (Hsiao et al., 2014).

Prostaglandin $\mathrm{E}_{2}$ is secreted from macrophages and ectopic endometrial cells and it is increased in the peritoneal cavity in cases of endometritis. This prostaglandin is included in the pathophysiology of the illness. Prostaglandin $\mathrm{E}_{2}$ influences leukocyte populations and provokes angiogenesis (Sacco et 
al., 2012).

\section{CONCLUSIONS AND RECOMMENDATIONS}

Microbiological examination of endometrial low volume uterine lavage is of great importance to diagnose precisely the causative agent either bacteria or fungi to select the proper antimicrobial agent. Cytology technique is rapid, relatively cheap, safe, and simple to apply under field circumstances and facilitates the detection of subclinical endometritis which is difficult to be diagnosed. IL6, $\mathrm{PGE}_{2}$ and $\mathrm{PGF}_{2 \alpha}$ are pro inflammatory cytokines, and their determination in serum of mares is important to predict early stages of endometritis to prevent its detrimental effect on fertility of mares.

\section{NOVELTY STATEMENT}

The current work was planned to diagnose endometritis in Arabian mares using microbiological and cytological examination together with IL6, $\mathrm{PGE}_{2}$ and $\mathrm{PGF}_{2}$ assessment to quickly treat those cases so fertility due to endometritis will be decreased accordingly.

\section{AUTHOR'S CONTRIBUTION}

All authors contributed to the design and implementation of the research, to the analysis of the results and to the writing of the manuscript.

\section{FUNDING}

This study was financed by Science and Technology Development Fund (STDF), project ID: 33342, Egypt.

\section{STATEMENT OF ANIMAL RIGHTS}

The current work was approved by the Ethical Use and Animal Care Committee of Faculty of Veterinary Medicine, Cairo University (Vet. CU28042021264).

\section{CONFLICT OF INTEREST}

The authors have declared no conflict of interests.

\section{REFERENCES}

-Aitken GJ (2012). Subclinical fungal endometritis in an 8-yearold Hanoverian mare. Can. Vet. J., 53(2): 196-198.

-Albihn A, Båverud V, Magnusson U (2003). Uterine microbiology and antimicrobial susceptibility in isolated bacteria from mares with fertility problems. Acta Vet. Scand., 44(3): 1-9. https://doi.org/10.1186/1751-0147-44-121

-Amorim MD, Gartley CJ, Foster RA, Hill A, Scholtz LE, Hayes A, Chenier TS (2016). Comparison of clinical signs, endometrial culture, endometrial cytology, uterine lowvolume lavage, and uterine biopsy and combinations in the diagnosis of equine endometritis. J. Equine Vet. Sci., 44: 54-61. https://doi.org/10.1016/j.jevs.2015.10.012

- Beltaire KA, Cheong SH, Coutinho da Silva MA (2012). Retrospective study on equine uterine fungal isolates and antifungal susceptibility patterns (1999-2011). Equine Vet. J., 44(Suppl 43): 84-87. https://doi.org/10.1111/j.20423306.2012.00608.x

- Bohn AA, Ferris RA, Patrick M, McCue PM (2014). Comparison of equine endometrial cytology samples collected with uterine swab, uterine brush, and low-volume lavage from healthy mares. Vet. Clin. Pathol., 43: 594-600. https://doi.org/10.1111/vcp.12194

-Bosh KA, Powell D, Shelton B, Zent W (2009). Reproductive performance measures among Thoroughbred mares in central Kentucky,during the 2004 mating season.Equine Vet.J.,41(9): 883-888. https://doi.org/10.2746/042516409X456068

- Carter JR (1984). Diagnostic procedures in veterinary bacteriology and mycology. $4^{\text {th }}$ edition, Charles C Thomas Publishers, Springfield.

- Causey RC (2006). Making sense of equine uterine infections: The many faces of physical clearance. Vet. J., 172: 405-421. https://doi.org/10.1016/j.tvj1.2005.08.005

- Couto MA, Hughes JP (1985). Intrauterine inoculation of a bacteria free filtrate of streptococcus zooepidemicus in clinically normal and infected mares. Equine Vet. Sci., 5: 81-86. https://doi.org/10.1016/S0737-0806(85)80053-8

- Fisher FW, Cook NB (1998). Fundamentals of diagnostic mycology. WB Saunders Company.

- Frontoso R, De Carlo E, Pasolini MP, van der Meulen K, Pagnini U, Iovane G, De Martino L (2008). Retrospective study of bacterial isolates and their antimicrobial susceptibilities in equine uteri during fertility problems. Res. Vet. Sci., 84(1): 1-6. https://doi.org/10.1016/j.rvsc.2007.02.008

- Holt JG, Krieg NR, Sneath PHA, Staley JT, Williams ST (1994). Bergy's manual of determinative bacteriology. $9^{\text {th }}$ edition, Williams and Wilkins, Baltimore, USA.

- Hsiao KY,Wu MH, Tsai SJ (2014). Roles of Prostaglandin E2 in Endometriosis. In: Harada T. (eds) Endometriosis. Springer, Tokyo. https://doi.org/10.1007/978-4-431-54421-0_9

- Ishikawa Y, Nakada K, HagiwaraK, Kirisawa R, Iwai H, Moriyoshi M, Sawamukai Y (2004). Changes in interleukin-6 concentration in peripheral blood of pre-and post-partum dairy cattle and its relationship to postpartum reproductive diseases. J. Vet. Med. Sci., 66(11): 1403-1408 https://doi.org/10.1292/jvms.66.1403.

-Kasimanickam RK, Kasimanickam VR, Olsen JR, Jeffress EJ, Moore DA, Kastelic JP (2013). Associations among serum pro-and anti-inflammatory cytokines, metabolic mediators, body condition, and uterine disease in postpartum dairy cows. Reprod. Biol. Endocrinol., 11(1): 1-13. https://doi. org/10.1186/1477-7827-11-103

- Knudsen O (1964). Endometrial cytology as a diagnostic aid in mares. Cornell Vet., 54: 415-422.

-LeBlanc M, MagsigJ, Stromberg AJ (2007).Use of a low-volume uterine flush for diagnosing endometritis in chronically infertile mares. Theriogenology, 68: 403-412. https://doi. org/10.1016/j.theriogenology.2007.04.038

-LeBlanc MM (2010). Advances in the diagnosis and treatment of chronic infectious and post-mating-induced endometritis in the mare. Reprod. Domest. Anim., 45: 21-27. https://doi. org/10.1111/j.1439-0531.2010.01634.x

-LeBlanc MM, Causey RC (2009). Clinical and subclinical endometritis in the mare: both threats to fertility. Reprod. 
Domest. Anim., 44(Suppl. 3): 10-22. https://doi. org/10.1111/j.1439-0531.2009.01485.x

- Moller NJ (2005). Endometritis in the mare: A diagonstic study comparing cultures from swab and biopsy. Theriogenology, 64: 510-518. https://doi.org/10.1016/j. theriogenology.2005.05.034

- Mosmann TR, Cherwinski H, Bond MW, Giedlin MA, Coffman RL (1986). Two types of murine helper T cell clone. I. Definition according to profiles of lymphokine activities and secreted proteins. J. Immunol. 136: 2348-2357.

- Overbeck W, Witte TS (2011). Heuwieser W: Comparison of three diagnostic methods to identify subclinical endometritis in mares. Theriogenology, 75: 1311-1318. https://doi. org/10.1016/j.theriogenology.2010.12.002

-Purswell BJ, Ley WB, Sriranganathan N, Bowen JM (1989). Aerobic and anaerobic bacterial flora in the postpartum mare. Equine Vet. Sci., 9: 141-144. https://doi.org/10.1016/ S0737-0806(89)80020-6

- Rakhila H, Bourcier N, AkoumA, Pouliot M (2015). Abnormal expression of prostaglandins $\mathrm{E} 2$ and $\mathrm{F} 2 \alpha$ receptors and transporters in patients with endometriosis. BioMed. Res. Int., 2015: 1-11. https://doi.org/10.1155/2015/808146

-Ricketts SW, Mackintosh ME (1987). Role of anaerobic bacteria in equine endometritis. J. Reprod. Fertil. Suppl., 35: 343-351.

- Riddle WT, LeBlanc MM, Stromberg AJ (2007). Relationships between uterine culture, cytology and pregnancy rates in a Thoroughbred practice. Theriogenology, 68(3): 395-402. https://doi.org/10.1016/j.theriogenology.2007.05.050

- Sacco K, Portelli M, Pollacco J, Schembri-Wismayer P, CallejaAgius J (2012). The role of prostaglandin E2 in endometriosis.
Gynecol. Endocrinol., 28(2): 134-138. https://doi.org/10.3 109/09513590.2011.588753

-Samson RA, HoubrakenJ, Thrane U, Frisvad JC, Andersen B (2010). Food and Indoor Fungi CBS Laboratory manual.

- Scott CJ (2020). A review of fungal endometritis in the mare. Equine Vet. Educ., 32(8): 444-448. https://doi.org/10.1111/ eve.13010

- Soliman MMH, Ata NS, El-Shafei HM, Kandil MMA (2019). Prevalence of toxigenic Aspergillus flavus in meat and meat products. Biosci. Res., 16(1): 822-829.

-SPSS 14, 2006. Statistical package for social science, SPSS for windows Release 14.0.0, 12 June, 2006. Standard Version, Copyright SPSS Inc., 1989-2006, All Rights Reserved. Copyright ${ }^{\circledR}$ SPSS Inc.

- Stout TA (2008). Fungal endometritis in the mare. Pferdeheilkunde. 24(1): 83-87. https://doi.org/10.21836/ PEM20080117

- Thalheimer R, Lawrence RG (2001). The economic loss to the Kentucky equine breeding industry from Mare Reproductive Loss Syndrome (MRLS) of 2001. Prepared for the Office of the Governor. Commonwealth of Kentucky.

-Troedsson MHT (2011). Endometritis. In: McKinnon AO, Squires EL, Vaala WE and Varner DD (2011). Equine Reproduction. $2^{\text {nd }}$ ed. Wiley-Blackwell. pp. 2608- 2619.

-Walter J, Wehrend A (2007). Exfoliative endometrial cytology as a diagnostic aid in the gynecological examination of broodmares. Pferdeheilk, 23: 481-488. https://doi. org/10.21836/PEM20070502

-Wu MY, Ho HN (2003). The role of cytokines in endometriosis. Am. J. Reprod. Immunol., 49(5): 285-296. https://doi. org/10.1034/j.1600-0897.2003.01207.x 